\title{
Influence of Accreditation on Quality Assurance: An Experiential Report of the Nigerian Public Universities
}

\author{
Rosemary Iyalekhuosa Osarenren-Osaghae \\ Faculty of Education, Educational Foundations and Management, Ambrose Alli University \\ Ekpoma, Edo State Nigeria
}

\begin{abstract}
This work is titled "Influence of Accreditation on quality Assurance: An Experiential Report of the Nigerian Public Universities" The Nigeria public universities were looked at with special attention on how the federal government of Nigeria handles universities education issues. This work was theoretically based but captured the practical experiences during accreditation of programmes in Nigerian public universities. Studies were cited to buttress points made. One of the studies cited used the population of academic staff to rank some factors expected to have caused incompetency in graduates produced in the public universities across Nigeria. It was found out that provision of human and material resources ranked top on the list. Based on the findings, recommendations were made.
\end{abstract}

\section{Introduction}

Educations are of different types, such as the formal, informal, non-formal, nomadic, etc. This work is concerned about the formal education gotten from the four walls of a building called school. To be specific, "THE UNIVERSITY". University education has been defined by lexicon university encyclopedia as "institute of higher education that teaches the most advanced learning of its time and place and usually also foster research in the sciences, humanities and social science. It has the authority to award degrees at bachelor, master and doctorial levels, traditionally in academic, non vocational disciplines but now also in technical and vocational areas [6]. University is a word derived from latin word "universitas." "stadium general" was her designation in ancient times or "school of universal learning". Gautsche and Pasto describe the university as an institution rooted in antiquity, unbroken in lineage for several centuries, survivor of the vicissitudes of time, accumulator, purveyor and creator of mankind's knowledge, one of civilization's sturdiest bulwarks against an uncertain future. Education have often been said to be an instrument of change, technological advancement, development of the nation and progress of mankind. In other words, education is an excellent tool for the overall transformation of individuals and nations. Nations with wisdom that know the value of education have utilized her to achieve their goals. There are so many benefits of education amongst them are: an eye-opener, independent and enlightened minds, skilled, proficient and proactive citizens, technological progress, comprehensive knowledge, standardized learning etc. The benefits of using education as a tool to develop a nation cannot be over emphasized. These benefits are not easy to come by because she needs dedication, investments, focus, enthusiasm, constant review, accountability etc., without which she may never be able to actualize the goals of any nation. Every proprietor of public or private schools needs to know this so as to prepare for this heculian task.

\section{Historical Background of Nigerian Public Universities}

A lot of researchers have extensively looked at the university system in Nigeria, nevertheless a brief historical background will do some good. In 13, June 1943, the Elliot commission under the British colony was set up to report on the organization and Facilities of the existing centres of higher education and to make recommendations regarding future university development. Through this commission the university college, Ibadan was born January 1948. This university and others founded in other African countries under the British colony were seen as elitist institutions and were roundly criticized that the content of education provided reflected colonial prejudices and not the needs of the local communities, the Ashby commission in April 1959, was set up to conduct an investigation into Nigeria's needs in the field of post secondary school certificate and higher education over the next twenty years (1960-1980). The report noted that the only convenient way of producing the needed manpower was by expanding the university system through the establishment of new universities. This recommendation led to the establishment of universities of Lagos, Zaria, Ibadan, Enugu. The commission also suggested a central coordinating body to oversee the new universities the 
recommendation led to the establishment of the Nigerian universities commission (NUC), established in 1962 as an advisory agency but later became a statutory body in 1974 as a parastatal under the federal ministry of education. The implementation of Ashby's report led to the first generation universities namely: universities of Nigeria, Ahmadu Bello, Ife, Lagos, Ibadan and Benin. The second generation universities consisted of universities of Jos, Calabar, Kano, Maiduguri, Sokoto, Port Harcourt and Ilorin. In 1977, the same year, the Joint Admission and Matriculation Board (JAMB) was created to regulate the admission of students into the universities taking cognizance of Federal characters, in the 1980s seven federal Universities of Technology were established namely: Federal Universities of Technology at Owerri 1980, Akure 1981, Yola 1981, Minna 1983, Abeokuta 1988, Bauchi 1988 and Makurdi 1988. Then an Open University now called University of Abuja was founded in 1980, University of Agriculture, Umudike 1992, University of Uyo 1991, Nnamdi Azikiwe University Awka 1992. These universities belonged to the $3^{\text {rd }}$ generation [9]. The 1979 constitution allowed states to establish their own Universities, the Anambra State University of Technology 1980, Bendel State University 1980, Rivers State University of Science and Technology 1980, Imo state university 1981, Universities of Ondo state, 1982, Ogun state 1982, Lagos State 1983 and Cross River 1984 were established. Then came the Cookey commission that set up by the federal government in 1981 looked into ways of encouraging Nigerian to seek for university education and it recommended among others free university education to any Nigerian who gets admitted into the university. Yet another commission the Longe commission was set up by the Head of State, Ibrahim Babangida on the $5^{\text {th }}$ Dec. 1990 headed by chief gray Longe to examine among others to determine the middle and higher level manpower supply and demand of the country and advise in the area of under or over production and under or over utilization of same, examine the availability and adequacy of academic staff in higher institution, investigate the nature, source and criteria of funding higher educational institutions with a view of improving the situation and guaranteeing steady source of funds for optimal functioning of these institutions. The longe commission identified higher education as the most powerful instrument for social reforms. The commission recommended among others that funds be provided for rehabilitation, restoration and consolidation of university education in ensuring decade, the staff exchange programme between Nigerian universities and oversees universities should be encouraged. After 1990, many more federal, states and private universities have been set up. The increase of these institutions brought a lot of problems instead of bring solutions to the nations development, student were not able to function after graduation because of inadequate human and material resources for teaching and learning to cope with the over population of students, inadequate funding, corrupt practices of various magnitude from officials in and out of the university community who were entrusted with the management of the universities, yet another panel set up by Abacha government, the Etsu nupe panel set up in 1997 on the state of affairs in Nigerian universities, it was recommened amongst other recommendation that $30 \%$ of Nigeria's annual budget be allocated to education, universities should depend on diversified domestic rather than external sources, as external sources are subjected to international political relations, all universities should engage in income generating activities. Then came the vision 2010 committee also set up by Abacha 1997, the committee also recommended $26 \%$ of annual national budget be allocated to education, but as usual corrupt practice will prevent a successful implementation of these laudable recommendations. Therefore instead of the universities to get better, they get worse because the dilapidated materials being used from the first generation universities is still in use today, there are no upgrades neither are there adequate additions to cope with the students population explosion. Practical courses were being taught theoretically, how can students be functional after graduation?

For reintiration the tertiary education goals according to the National Policy on Education [1] are:

- To contribute to national development through high level relevant manpower training.

- To develop and inculcate proper values for the survival of the individual and society.

- To develop the intellectual capability of individuals to understand and appreciate their local and external environments.

- To acquire both physical and intellectual skills which will enable individuals to be self-reliant and useful members of the society.

- To promote and encourage scholarship and community service

- To forge and cement national unity

- To promote national and international understanding and interaction.

These goals are to be actualized through: teaching, research and development, virile staff development programmes, generation and dissemination of knowledge, a variety of modes of programmes such as full-time and sandwich programmes, access to training fund such as industrial training fund (ITF), students industrial work experience scheme (SIWES), maintenance of 
minimum educational standards through appropriate agencies, inter institutional cooperation and dedicated service to the community through extramoral and extension services.

The inability for Nigeria to be able to actualize these laudable goals is not a surprise but it brings concerns to the hearts of all stakeholders. Nigeria as a nation has a wonderful, well written national policy on education which states what education is expected to do for the nation, thus; (a) a free and democratic society, (b) a just and egalitarian society, (c) a united, strong and self-reliant nation, (d) a great and dynamic economy, (e) a land full of bright opportunities for all citizens, Federal Republic of Nigeria [7]. From the above goals, education is seen as an instrument for change. Therefore, education must be geared towards the inculcation of the following among others:

- Respect for the worth and dignity of the individual

- Faith in man's ability to make rational decision

- Acquisition of competences necessary for self reliance [7].

The problem however is bringing these words to reality. It is in full realization of the pivotal role education can play in bringing about change that it is stated in the national policy of education that education is the most important instrument of change [7]. Over the years, it has been a huge problem to adequately fund education in Nigeria. The inability of the federal government to do this, led to the introduction of private universities where individuals, corporate bodies and missionary organizations are empowered to run university. The government has tried to allocate a portion of the yearly budget to education but still fails to release all the financial responsibility in the budget to the universities concerned even though the percentage is far less than UNESCO's recommendation. This act has led to untold hardship to the public universities. It has brought incessant strikes which are at times local and sometimes national. At times when the national strike is called off, the different state universities of the federation start their own negotiations with their various state governments because many times the state governments refuse to accept the financial responsibilities due to lack of money they say! This is probably one of the reasons why the federal universities are better funded than the state universities. How have Nigerian universities fared in the world ranking? According to okecha (2008) the best university in Nigeria is not among the best 500 universities in the world but infact the $5,834^{\text {th }}$ in the world and it is among the first generation university. Academic Staff of Universities (ASUU) have over the years fought for university funding and upgrade of material resources but all to no avail rather the government in power threatens their jobs, lives etc. for example during the 1973 struggle for staff welfare and conditions of service, Gowon ordered all university lecturers to pack and go, and the academic staff lost but on a second thought, it was actually Nigeria that lost. Researches believed Gowon's era rendered the academics vulnerable to the delight of the uninformed citizens. Then came the era of Mohammed and Obasanjo in 1975 , they sacked the vice chancellor of university of Ibadan on a convocation ceremony day. Then came the era of sole administratorship, in this era, people who were not qualified are appointed as sole administrators to replace and do the job of a vice chancellor, this was done by Abacha. From records the military heads of states had no regards for the university education. Vice chancellors are now being appointed hardly by election but by political dictates, tribalism, political affiliation etc.

This work focused on human and material investments in the university education in Nigeria. The university is the highest level of educational system anywhere in the world and it is expected that graduates from this level of education have what it takes to move themselves, their community and nation forward. Nigeria can easily be referred to as an educogenic nation because of her love for education. Nigeria has well over one hundred universities both public and private in her 53 years of existence, that is an average of two universities a year to accommodate the teaming youths yearning for university education so as to acquire skills and certificates, but from observations employers always complain that graduates from Nigerian universities are not competent, not confident and ill-prepared for the world of work. It is either they end up as job seekers or be re-trained by employers when they manage to get jobs. This is a difficult fact to swallow but it is the reality on ground. People are quick to apportion blames on school authorities and university teachers who themselves need help to be able to manage the schools effectively and efficiently to actualize their goals. This work went searching for the cause(s) of the problem, two important factors to the success of any form of education came to mind, and these were human and material resources, available for teaching and learning in the universities. Several studies have actually been carried out about these two factors in the past including the one by Osarenren-Osaghae [3] but in order to update knowledge, latest information was necessary. In a case study by Osarenren-Osaghae on Nigerian graduates: implications for national security, fifteen public universities (8 Federal government owned and 7 state government owned) were randomly selected for study, namely: University of Ibadan, University of Benin, Ahmadu Bello University, Obafemi Awolowo University, University of Nigeria, University of Port Harcourt. Federal University of Technology Minna, University of Uyo, Ambrose Alli University, Abia State 
University, Akwa-Ibom State University, Benue State University, Delta State University, Ekiti State University, Kaduna State University. Alongside provision of human and material resources were other factors such as poor teaching, ineffective administration, student's vices such as examination malpractice, cultism, staff incessant strikes, funding, students reading habits, proprietors' nonimplementation of agreements reached between them and staff, proprietors incessant interferences in the day to day running of the schools. These factors were also looked at because they also brought concerns to the universities. In other to guide the study, four questions were asked out of which three hypotheses were formulated. The respondents who were three thousand and nineteen academic staff from the fifteen universities across the nation were made to rank the above listed factors that contributed to the cause(s) of incompetent/unskilled graduates in Nigeria. The questionnaire used had 4 sections, section one had respondents' bio-data and section two had items for hypotheses one and two, section three for hypothesis three and section four for question four, the content of the instrument was validated by experts and the reliability value was 0.87 which was found reliable. The questionnaires were administered to the respondents and same were retrieved by the researcher and assistants. The data gathered were subjected to a statistical analysis using the pearson product moment correlation coefficient for hypotheses one and two, t-test for two independent samples was used for hypothesis three and mean for ranking the factors in question four. The study found out in question four that the human and material resources factors were at the top of the list of factors responsible for graduate's incompetency [4]. These findings did not come as a surprise, as an academic staff for over seventeen years in one of the universities in Nigeria, a lot of observations have attested to this fact. This study is in support of [3], which sought to know the availability and adequacy of the human and material resources for teaching and learning of skilled-based courses in Nigerian universities, where 10 public universities across the nation were picked by random sampling. Students and academic staff participated in this study, to guide the study, three research questions were asked and two hypotheses were formulated. The questionnaire consisted of four sections (A, B, C, D), A for Bio-data of respondents, $\mathrm{B}$ for items on human resources, $\mathrm{C}$ for items on material resources and $\mathrm{D}$ was a checklist on the availability and adequacy of human and material resources for teaching and learning, this was compared to the minimum standard requirement by National Universities Commission (NUC). The Ttest, mean and simple percentage was the statistics used for the analysis. The findings were that; (1) Human resources (staff) were inadequate, (2)
Material resources were inadequate, (3) The available human and material resources did not meet the minimum standard recommended by NUC, (4) There was no significant difference in the mean responses of the final year students and academic staff regarding the availability and adequacy of human and material resources in the universities. Okecha (2008) in his work titled "the Nigerian university: an ivory tower with neither ivory nor tower" x-rayed three generations of universities in Nigeria, and concluded that the first generations were better than the second like wise the second were better than the third in other words the universities deteriorates as the years rolled by and the government seem not to be able to do anything in terms of revamping them because all efforts have proved abortive. It was concluded amongst other conclusions that the government should put in more effort.

\section{NUC Accreditation Exercise and quality assurance in Nigerian public Universities}

\subsection{Accreditation}

The main functions of the National University Commission (NUC) are outlined below:

- Granting approval for all academic programmes run in the Nigerian universities

- Granting approval for the establishment of all higher education institutions offering degree programmes.

- Ensuring quality assurance for all academic programmes

- Serving as a channel for all external support in the Nigerian universities.

There are five major departments namely departments of quality assurance, academic planning and research, physical planning and development, information and communication technology and finance and administration. For the purpose of accreditation, the quality assurance department is of most importance in the article. The main job of this department is to guarantee Nigerian's quality university education in spite of the increasing population and institutions. The division under the quality control departments are undergraduate quality assurance, post graduate quality assurance, federal universities monitoring and evaluation, state universities monitoring and evaluation. The accreditation panel uses the NUC uniform guidelines and criteria to ensure fair play and justice in their assessment requirement and in their final verdicts. Meanwhile these guideline and criteria have not been renewed for over twenty years. The panel are normally expected to see in every department items 
listed in assessment requirement, members of the panel are also expected to interact with students from whom vital information could be obtained; however some of the accreditation panels have been found wanting, the accreditation exercise have been grossly abused according to Okecha [9] which said:.

- Some panels do not insist on seeing physically all the listed academic staff.

- Some universities hire some academics deficient in honour for a day or two parade themselves as staff during accreditation.

- Some institutions borrow equipment and chemicals from sister universities.

- Some department fraudulently list professors of other universities (without their consent) as their staff.

- Departments showcase borrowed books and journals from other institutions

- some panel see over crowed lecture halls and over look

- In experienced academic are recruited to serve as members of accreditation panels.

- Some panels receive bribes from institutions

- Some panels are always in a hurry to return to their offices doing their jobs half hazardly in trying to do two days work in a few hours [9].

It may be of interest to know that a lot of millions of money are spent yearly by the federal government on visitations by panel to schools.

The drama begins when the accreditation team has to come to the university to carry out their investigations. A date is set by the Commission and information is passed to the school to be visited. The lists of programme requirements are also sent to the school. In preparation, the schools go out of their way to borrow equipments, window dressing the school by painting the buildings of the faculty to be visited, cutting the grass, replace broken windows, doors, chairs and tables, roads are graded and sometimes tard, people are borrowed to stand as staff during accreditation (this is just to say a few), all because the school wants a programme accredited, this is because without accreditation, the school is not qualified to run the programme and certificate not recognized. The team arrives on the set day to see everywhere looking almost perfect, everybody is full of fake smiles and pretending to be happy, it is a sorry sight! In some cases the school will have to source for money from other sources such as banks, other organizations/bodies even individuals e.t.c to prepare for the big day. The accreditation team is lodged in the finest hotels around and given the best of times. The team goes round the school to see what is on ground as compared to their expectations; observations are made which in most cases are swept under the carpet and silenced, at the end of the visitation. When the team is ready to go, gifts are given to each member; this is a strategy to suppress whatever negative decision or intension against the accreditation, so that the school can continue to run that programme unqualified. All borrowed human and material resources goes back to their owners when the team goes away, who is deceiving who? Quality assurance are made of several ingredients in the university system of education, some of which include: University Autonomy, Academic Freedom, Provision of Adequate Human and Material Resources, Adequate Funding, Staff Welfare, Staff Dedication, Good Leadership, Staff Training, Effective and Efficient Administration, Proprietors not Interfering in the day to day running of the school unless of course if he/she is the manager etc. Quality provision breeds quality graduates there are no two ways about it. It is either the nation swims or sinks, in other words it is either quality provisions are made to bring about quality education for the youths who are the future leaders and developers of the nation or the nation should forget about using education as a tool to bring about national development, advancement in technology and change in her citizenry.

\section{Discussion}

The government of a nation has the responsibility to educate its citizens if it is to bring about the "change" so desired; if the national policy states that education shall continue to be highly rated in the national development plans how come it is not well funded?, How come when agreements are reached between the various cadre of staff in the university and the government, they are never upheld, the government always slack in its own part of the bargain to implement agreements. The government claims to love education as a tool for national development and yet slacks in the provision of those resources that would make education succeed. Who is deceiving who?

This attitude of the government is like a child's play such as convincing the staff to go back to work with the promise to implement agreement reached, workers indeed go back to work with the believe that the government will implement agreements signed and sealed, but only to be betrayed. Government do not have respect for promises and agreements made to university workers, nor have respect for university education, yet aspirations of Nigeria being one of the top most technologically advanced country is in the front burner. Who is deceiving who?. A classical example of a national strike born out of nonimplementation of agreement reached since 2009, not yet implemented is currently on. It started on the $1^{\text {st }}$ July 2013 and ended in Dec, 2013; check appendix 1 for more information. Academic staff are handicapped in teaching, research and community service, and graduates bred are half baked, theory based, outdated, incompetent and can not function 
this is frustrating for the academic staff. The implications of this is continuous societal vices some of which include: cultism, armed robbery, assassinations, kidnappings, incessant violence, blood thirsty groups emerging only to ask for amnesty after much harm has been done to the nation and her citizens, etc. major parts of these problems would have been avoided if these youths were given adequate training in their schools to make them competently skilled and confident in themselves so that when jobs are not forthcoming, they can make one with the skill they have acquired in their school days instead of making troubles to get attention. Angry youths are destructive youths. Appendix II gives some pictorial evidences of the scenarios in Nigeria public universities.

\section{Conclusion}

The absence of adequate provision of human and material resources for management, teaching and learning in the public universities in Nigeria such as to produce quality and competent graduates in all fields of endeavour, education goals and national aspirations will be a fallacy. The nation will never experience development even in the face of transferred technology because to transfer technology is one thing to manage and maintain the transferred technology is another. Secondly, when the future leaders (youths) of the nation are not adequately trained to tackle developmental issues, they will continue to run to safe havens, seek asylums and pitch tent with those nations who have made it: therefore, the future is lost to other nations.

\section{Recommendations}

The problems currently exiting in the Nigerian public university system can be drastically reduced when the following recommendations are adhered to:

1. Proprietors of the Universities which in this case are Federal and State Governments must adequately provide the needs of the universities as specified above. So as to breed quality, competent and skilled graduates for the nation.

2. Impromptu visits by Accreditation Teams are highly recommended to know the truth and not window dressing it. Accreditation teams must know that they are in schools for business not pleasure.

3. Motivation/welfare of Staff is another very important factor that will help the universities run smoothly without interferences of strikes and will also promote positive attitude to work. Osarenren-Osaghae [5], Fried Lander [2].

4. Management staff which includes: Academic and Administrative staff must be focused, dedicated, diligent, steadfast in doing their jobs and constantly updating their knowledge.
5. University Autonomy and Academic Freedom must be granted and implemented in full [5].

6. The government should implement recommendations put up by various studies and commissions set up for this purpose.

\section{References}

[1] Federal Republic of Nigeria (2004); National Policy on Education; $4^{\text {th }}$ edition; Lagos; National Educational Research Development Commission (NERDC) press.

[2] Friedlander, F. (2006); Motivation to Work and Organizational Performance. Journal of Applied Psychology; 50(3), 72-79.

[3] Osarenren-Osaghae, R.I. and Irabor, Q.O. (2012), Availability and Adequacy of Human and Material Resources for the Teaching of Skilled-Based Courses in Nigeria Public Universities, Journal of Sociology and Anthropology, 3(1) 15-27 India; Kre Publishers.

[4]Osarenren-Osaghae, R. I., (2013), Relationship between Motivation and Attitude to work by Academic Staff of Public Universities in Edo and Delta states of Nigeria, an Unpublished Ph.D. Theses; Ambrose Alli University, Ekpoma.

[5]Osarenren-Osaghae, R. I., (2013), Nigeria Graduates: Implications for National Security. A Conference paper delivered at the $32^{\text {nd }}$ Annual National Conference of the National Association of Educational Administration and Planning (NAEAP), an affiliate of Commonwealth Council for Educational Administration and Management (CCEAM) held at University of Ilorin, Kwara State Nigeria, October $8^{\text {th }}$ to $11^{\text {th }}, 2013$.

[6] Lexicon publications, inc., (1989), The world book encyclopedia, New York, vol.19:469.

[7] Federal Republic of Nigeria (2004). National policy on education ( $4^{\text {th }}$ edition).

[8] NUC, Abuja, (2007), http://www.nuc.edu.ng/ universities.htm

[9] Okecha, S. A., (2008), the Nigerian university: an ivory tower with neither ivory nor tower, Imo eduedy publications. 